\title{
Hydrogeochemical and isotopic study of the origins of groundwater salinization in the deep confined aquifer of northern Yangtze River
}

\author{
Qi Zhao ${ }^{1}$, Xiaosi $\mathrm{Su}^{2}$, and Yiqun $\mathrm{Gan}^{1, *}$ \\ ${ }^{1}$ School of Environmental Studies, China University of Geosciences, 430074 Wuhan, China \\ ${ }^{2}$ College of Construction Engineering, Jilin University, 130021 Changchun, China
}

\begin{abstract}
The deep confined water of coastal plain of northern Yangtze River suffers salinization. That results from overexploitation. This work aims to investigate the geochemical processes that lead to the salinization for this aquifer. Multiple environmental tracers of major ions, minor ions and isotopes $\left({ }^{18} \mathrm{O},{ }^{87} \mathrm{Sr},{ }^{13} \mathrm{C}\right)$ were used to yield reasonable conclusions. The TDS of the aquifer ranges from 387 to $2600 \mathrm{mg} / \mathrm{L}$. The aquifer is mainly composed of fresh water. Brackish water is distributed in the eastern and southern coastal areas, and is scattered in some inland areas. The water chemical type evolves from $\mathrm{HCO}_{3}-\mathrm{Na}$ to $\mathrm{Cl}-\mathrm{Na}$ as TDS increases. Groundwater salinization is caused by mixing with saline water of marine origin. The aquifer is also affected by other hydrochemical processes. Silicate weathering and carbonate dissolution add $\mathrm{Na}^{+}, \mathrm{K}^{+}, \mathrm{Ca}^{2+}$, $\mathrm{Mg}^{2+}$ and $\mathrm{HCO}_{3}^{-}$to groundwater. Sulfate reduction makes sulfate be deficient and $\mathrm{HCO}_{3}{ }^{-}$be enriched. Carbonate minerals equilibrium limits the increase in the concentrations of $\mathrm{Ca}^{2+}, \mathrm{Mg}^{2+}$ and $\mathrm{HCO}_{3}{ }^{-}$. Cation exchange reduces the concentration of $\mathrm{Ca}^{2+}+\mathrm{Mg}^{2+}$ and increases the concentration of $\mathrm{Na}^{+}+\mathrm{K}^{+}$. The aforementioned processes have a combined influence on the formation of fresh water with $\mathrm{HCO}_{3}-\mathrm{Na}$ type.
\end{abstract}

\section{Introduction}

Most of the coastal areas are economically developed with dense population and large water demand. Groundwater has become the main source of fresh water in coastal areas because of its good water quality and convenient for exploitation. With the rapid development of society and economy in coastal areas, the demand for freshwater resources has increased tremendously. Coastal groundwater in many areas suffers overexploitation, which induces some environmental problems. Salinization is the most common problem and limits the sustainable utilization of groundwater [1-4]. In order to prevent further deterioration of groundwater quality, it is of significant importance to fully understand the spatial distribution of salinity and its origin in this aquifer.

The northern Yangtze River near coastal plain is underlain by a multilayer sequence of unconsolidated, predominantly sand and gravel aquifers separated by silt and clay confining units. According to the burial condition, the unconsolidated aquifer can be divided into

\footnotetext{
*Corresponding author: yiqungan@ cug.edu.cn
} 
unconfined and confined aquifers. The confined aquifer can be further divided into a shallow and a deep confined aquifer. The deep confined aquifer (DCA for short) is the focus of this study. The DCA lies at a depth of 150 270 m below the land surface, and has an average thickness of $50 \mathrm{~m}$. The aquifer comprises early Pleistocene fluvial/lacustrine deposits of fine to coarse sand and gravels. The exploitation of deep confined water (DCW for short) in the study area began in 1971. Since then, in order to meet the water demand for economic and social development, the amount and scope of groundwater exploitation have increased rapidly. Due to overexploitation, the piezometric level of DCW declines rapidly forming two depression cones (Fig. 1) and some part of the DCW suffers salinization. Many researches have addressed salinization origin of DCW of the study area. But their conclusions are controversial and need to be further studied [5, 6]. Besides, there is little research that deals with the chemical mechanisms for the formation of deep confined fresh water which is also of great importance to sustainable development of DCW.

In this paper, we aim to investigate the origin of groundwater salinization of DCW and identify the major hydrogeochemical processes controlling its chemistry. We believe this study will provide useful insights for other regions with similar hydrogeological conditions, both in China and globally.

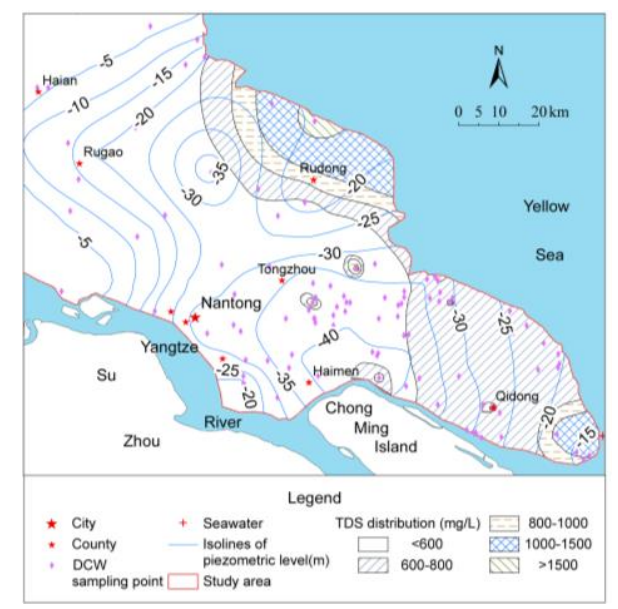

Fig. 1. Location map of the study area, showing the sampling sites, isolines of piezometric level, and TDS distribution of the deep confined water.

\section{Methods}

To fully understand local hydrogeological conditions, 101 representative groundwater samples from production wells and observation wells were taken from the deep confined aquifer and one seawater sample from Yellow sea (Fig. 1) in October to December from 2012 to 2014. Temperature, $\mathrm{pH}$ and Alkalinity were directly measured in situ. The detailed analytical methods used for $\mathrm{Na}^{+}, \mathrm{K}^{+}, \mathrm{Ca}^{2+}, \mathrm{Mg}^{2+}, \mathrm{Cl}^{-}, \mathrm{SO}_{4}{ }^{2-}, \mathrm{NO}_{3}{ }^{-}, \mathrm{Br}, \mathrm{Sr},{ }^{18} \mathrm{O},{ }^{13} \mathrm{C},{ }^{87} \mathrm{Sr} /{ }^{86} \mathrm{Sr}$ are those reported in [7].

\section{Results}

The TDS value of DCW samples ranges from $387 \mathrm{mg} / \mathrm{L}$ to $2600 \mathrm{mg} / \mathrm{L}$ with an average value of $663 \mathrm{mg} / \mathrm{L}$. The $\mathrm{DCW}$ in the study area is mainly composed of fresh water. Brackish water is present in the eastern and southern coastal areas, and scatters in some inland areas. The TDS content increases gradually from inland to the coastal area (Fig. 1). 
The water type of most fresh water samples is $\mathrm{HCO}_{3}-\mathrm{Na}$. With the rise of TDS value, the water type of the DCW evolves to Cl-Na. The nitrate concentration of the DCW samples is $<0.2 \sim 5.1 \mathrm{mg} / \mathrm{L}$ which is below the drinking water limit of World Health Organization (WHO) of $50 \mathrm{mg} / \mathrm{L}$ indicating little anthropogenic effect on water quality.

\section{Discussion}

\subsection{Salinization origin}

The $\delta^{18} \mathrm{O}$ of brackish DCW samples become heavier with the increase of $\mathrm{Cl}^{-}$concentration (Fig. 2a), which indicates mixing with saline water with relatively heavier $\delta^{18} \mathrm{O}$. The $\gamma \mathrm{Br} / \gamma \mathrm{Cl}$ of DCW samples range from 0.0008 to 0.0022 with an average value of 0.0012 , which is close to that of seawater. If the salinity of groundwater was mainly derived from halite dissolution, its $\gamma \mathrm{Br} / \gamma \mathrm{Cl}$ will be much lower than 0.0001 . So halite dissolution has little impact on the chemical composition of DCW. With the increase of $\mathrm{Cl}^{-}$concentration, the $\gamma \mathrm{Br} / \gamma \mathrm{Cl}$ of DCW samples shows no obvious change, but its trend fluctuates near the seawater line (Fig. 2b). This phenomenon indicates that the salinity of brackish water may be derived from a marine source or by evapotranspiration. As the DCA is buried below ground surface about $150 \mathrm{~m}$, the evapotranspiration process is very weak. So the salinity of DCW brackish water likely originates from mixing with saline water of marine origin which may be seawater or overlying shallow confined saline water.
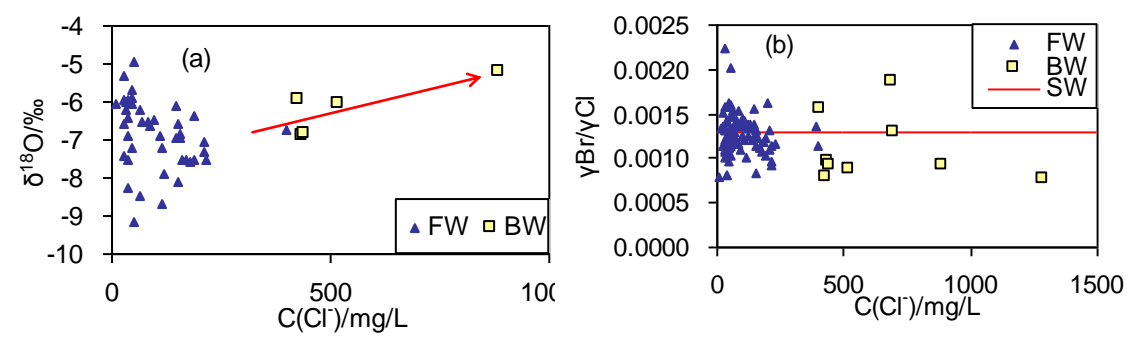

Fig. 2. Binary plot between $\mathrm{Cl}^{-}$and (a) $\delta^{18} \mathrm{O}$, (b) $\gamma \mathrm{Br} / \gamma \mathrm{Cl}$. FW, BW, SW refer to fresh water, brackish water and seawater.

\subsection{Hydrogeochemical processes}

\subsubsection{Silicate weathering and carbonate minerals dissolution}

The average value of $\gamma \mathrm{Na} / \gamma \mathrm{Cl}$ of DCW samples is 3.37, much greater than 1, indicating silicate weathering. With the increase of $\mathrm{Cl}^{-}$concentration, the $\gamma \mathrm{Na} / \gamma \mathrm{Cl}$ decreases gradually and approaches the seawater line (Fig. 3a), which further confirms that the salinity of brackish water samples is from a marine source.

Because the concentration of $\mathrm{Ca}^{2+}$ and $\mathrm{Mg}^{2+}$ of the DCW samples are well correlated with that of $\mathrm{Sr}$, the correlation coefficients are 0.93 and 0.96 respectively, showing that $\mathrm{Ca}^{2+}, \mathrm{Mg}^{2+}$ and $\mathrm{Sr}$ are from the same source. The source of $\mathrm{Ca}^{2+}$ and $\mathrm{Mg}^{2+}$ in the DCW can be revealed by the relationship between $\mathrm{Sr}$ and ${ }^{87} \mathrm{Sr} /{ }^{86} \mathrm{Sr}$. Compared with carbonate minerals, silicate minerals have lower $\mathrm{Sr}$ content and higher $\mathrm{Na}$ content. So the value of $\gamma \mathrm{Sr} / \gamma \mathrm{Na}$ of silicate minerals is lower than that of carbonate minerals. The ${ }^{87} \mathrm{Sr} /{ }^{86} \mathrm{Sr}$ ratio of silicate minerals is higher than that of carbonate minerals. As is shown in Fig. 3b, two endmembers can be identified. One is silicate minerals with low $\gamma \mathrm{Sr} / \gamma \mathrm{Na}$ and high ${ }^{87} \mathrm{Sr} /{ }^{86} \mathrm{Sr}$, the 
other one is carbonate minerals with high $\gamma \mathrm{Sr} / \gamma \mathrm{Na}$ and low ${ }^{87} \mathrm{Sr} /{ }^{86} \mathrm{Sr}$. The difference of $\gamma \mathrm{Sr} / \gamma \mathrm{Na}$ and ${ }^{87} \mathrm{Sr} /{ }^{86} \mathrm{Sr}$ of DCW samples is due to dissolution of silicate minerals and carbonate minerals of different proportions. Most of DCW samples are low in ${ }^{87} \mathrm{Sr} /{ }^{86} \mathrm{Sr}$ and high in $\gamma \mathrm{Sr} / \gamma \mathrm{Na}$ indicating the $\mathrm{Ca}^{2+}$ and $\mathrm{Mg}^{2+}$ of DCW are mainly derived from carbonate minerals dissolution.
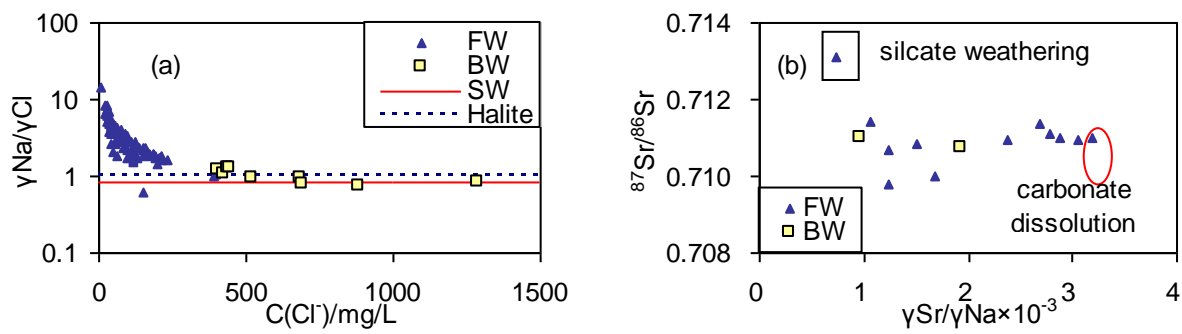

Fig. 3. Binary plot between (a) $\mathrm{Cl}^{-}$and $\gamma \mathrm{Na} / \gamma \mathrm{Cl}$, (b) $\gamma \mathrm{Sr} / \gamma \mathrm{Na}$ and ${ }^{87} \mathrm{Sr} /{ }^{86} \mathrm{Sr}$. FW, BW, SW refer to fresh water, brackish water and seawater.

\subsubsection{Sulfate reduction}

The fresh DCW samples with low TDS, indicating the least influence of seawater have $\gamma \mathrm{SO}_{4} / \gamma \mathrm{Cl}$ values around 0.10 , which is similar with that of seawater $(0.10)$. If seawater mixing is the only process controlling the $\gamma \mathrm{SO}_{4} / \gamma \mathrm{Cl}$ values, they will fluctuate around the marine ratio. However, most of DCW samples show lower $\gamma \mathrm{SO}_{4} / \gamma \mathrm{Cl}$ values (an average value of 0.06 ) than seawater indicating that other process reduces the sulfate concentration. This process may be gypsum precipitation or sulfate reduction. The saturation index (SI) of DCW samples relative to gypsum is $-3.75 \sim-1.55$, much less than 0 , which indicates that gypsum is under saturated. With the increase of $\mathrm{HCO}_{3}{ }^{-}$concentration, the value of $\delta^{13} \mathrm{C}$ tends to be deficient (Fig. 4a), which proves the existence of sulfate reduction, because sulfate reduction produces relatively deficient $\delta^{13} \mathrm{C}_{\text {of }} \mathrm{HCO}_{3}^{-}$(Eq. 1).

$$
2 \mathrm{CH}_{2} \mathrm{O}+\mathrm{SO}_{4}{ }^{2-} \rightarrow \mathrm{H}_{2} \mathrm{~S}+2 \mathrm{HCO}_{3}^{-}
$$

\subsubsection{Equilibrium of carbonate minerals}

The SI of DCW samples with respect to calcite and dolomite were calculated. The results show that the SI of DCW samples with respect to calcite and dolomite are all greater than 0 , varying from 0.15 to 1.41 and from 0.22 to 2.87 respectively indicating that DCW samples are all oversaturated with calcite and dolomite. Calcite and dolomite tend to precipitate to limit the growth of concentration of $\mathrm{Ca}^{2+}, \mathrm{Mg}^{2+}$ and $\mathrm{HCO}_{3}{ }^{-}$of DCW.

\subsubsection{Cation exchange}

For DCW samples with $\mathrm{TDS}<600 \mathrm{mg} / \mathrm{L}$, the proportion of $\mathrm{Na}^{+}+\mathrm{K}^{+}$increases and $\mathrm{Ca}^{2+}+\mathrm{Mg}^{2+}$ decreases with slight increase of TDS content (Fig. 4b), indicating direct cation exchange (Eq. 2). The adsorption of $1 \mathrm{~mol} \mathrm{Ca}^{2+}$ will release $2 \mathrm{~mol} \mathrm{Na}^{+}$(Eq. 2) while the gram formula weight for $1 \mathrm{~mol} \mathrm{Ca}{ }^{2+}(40)$ is less than that of $2 \mathrm{~mol} \mathrm{Na}^{+}$(46). Therefore, direct cation exchange causes slight increase of TDS content of DCW. DCW samples with TDS content $600 \sim 1000 \mathrm{mg} / \mathrm{L}$, the proportion of $\mathrm{Na}^{+}+\mathrm{K}^{+}$and $\mathrm{Ca}^{2+}+\mathrm{Mg}^{2+}$ remains unchanged with the rises of TDS content indicating that cation exchange does not occur. The proportion of $\mathrm{Na}^{+}+\mathrm{K}^{+}$decreases and $\mathrm{Ca}^{2+}+\mathrm{Mg}^{2+}$ increases of brackish water samples 
with the rises of TDS content which shows that reverse cation exchange (Eq. 3) may occur to reduce the concentration of $\mathrm{Na}^{+}+\mathrm{K}^{+}$after mixing with saline water. The clay minerals of aquifer and aquitards appear to be exchanger for this process. The slope of trend line of $\mathrm{Na}^{+}+\mathrm{K}^{+}$proportion ascent of brackish water samples is small of -0.0025 showing weak impact of reverse cation exchange on water quality of brackish water.

$$
\begin{aligned}
& 2 \mathrm{Na}-\mathrm{X}+\mathrm{Ca}^{2+} \rightarrow 2 \mathrm{Na}^{+}+\mathrm{Ca}-\mathrm{X}_{2} \\
& 2 \mathrm{Na}^{+}+\mathrm{Ca}-\mathrm{X}_{2} \rightarrow 2 \mathrm{Na}-\mathrm{X}+\mathrm{Ca}^{2+}
\end{aligned}
$$
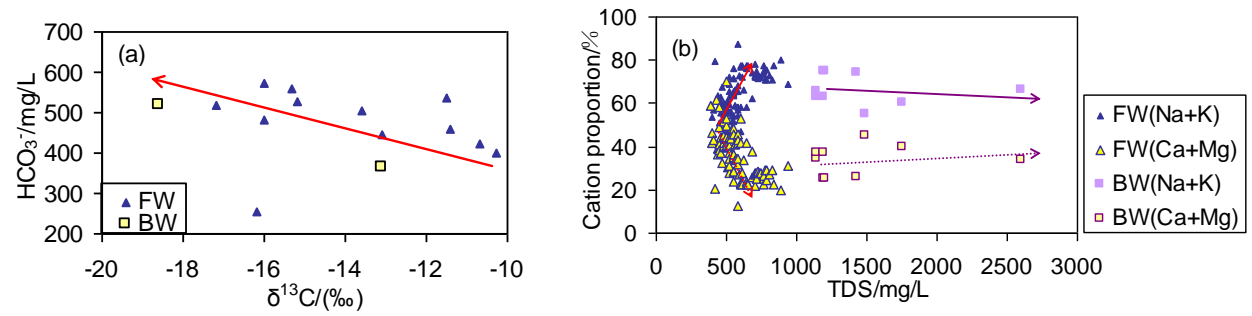

Fig. 4. The relationship between (a) $\delta^{13} \mathrm{C}$ and $\mathrm{HCO}_{3}{ }^{-}$, (b) TDS value and major cation proportion. $\mathrm{FW}$, $\mathrm{BW}$ refers to fresh water and brackish water.

\section{Conclusions}

The DCW in the study area is mainly composed of fresh water. Brackish water is present mainly in the central and southern coastal areas. The water type of DCW samples evolves from $\mathrm{HCO}_{3}-\mathrm{Na}$ to $\mathrm{Cl}-\mathrm{Na}$ with the increase of TDS content. The DCW brackish water samples have $\gamma \mathrm{Br} / \gamma \mathrm{Cl}$ ratios close to seawater, relatively enriched ${ }^{18} \mathrm{O}$ showing that the origin of salinization of DCW is from mixing with saline water of marine origin. In addition, water-rock interaction also plays a certain role in the formation of chemical compositions of DCW. $\mathrm{Ca}^{2+}$ and $\mathrm{Mg}^{2+}$ are mainly derived from dissolution of carbonate minerals; $\mathrm{K}^{+}$and $\mathrm{Na}^{+}$are mainly derived from silicate weathering. Silicate weathering also releases $\mathrm{Ca}^{2+}, \mathrm{Mg}^{2+}$, and sulfate reduction increases $\mathrm{HCO}_{3}{ }^{-}$, resulting in carbonate minerals oversaturation. Then the carbonate minerals precipitate to limit growth of the concentration of $\mathrm{Ca}^{2+}, \mathrm{Mg}^{2+}$ and $\mathrm{HCO}_{3}{ }^{-}$. Combined with the cation exchange, the aforementioned processes make deep confined fresh water be of $\mathrm{HCO}_{3}-\mathrm{Na}$ type. The brackish water is also influenced by reverse cation exchange albeit to a limited extent.

Acknowledgements This work was funded by the Groundwater Circulation and Water Chemical Evolution Project of the Jiangsu Coastal Area ([2012]01-002-007). The authors thank the Geological Survey of Jiangsu Province for assistance with the study's fieldwork and for supplying basic hydrogeological information.

\section{References}

1. D.M. Han, X.F. Song, M.J. Currell, J.L. Yang, G.Q. Xiao, J. Hydrol, 508, 12-27 (2014)

2. E. Petelet-Giraud, P. Negrel, B. Aunay, B. Ladouche, V. Bailly-Comte, C. Guerrot, C. Flehoc, P. Pezard, J. Lofi, N. Dorfliger, Sci Total Environ, 566-567, 398-415 (2016)

3. M. Bahir, D. Ouazar, S. Ouhamdouch, Environ Sci Pollut Res. 25, 24992-25004 (2018)

4. D.M. Han, M.J. Currell, Hydrol Earth Syst Sc, 22, 3473-3491 (2018)

5. W.H. Shan, W.B. Xing, J. Geol (in Chinese) 32, 286-291 (2008) 
6. H.F. Zhou, H.B. Tan, X.Y. Zhang, Geochimica (in Chinese) 40, 566-576 (2011)

7. Q.Zhao, X.S. Su, B. Kang, Y. Zhang, X.C. Wu, M.Y. Liu, Appl Geochem 86, 49-58 (2017) 